\title{
Basic Knowledge of Physical Education Students About Olympism And Concepts Related to Excessive Training: What is the Legacy in Rio De Janeiro - 2016?
}

\author{
Thiago Guimarães ${ }^{1}$, Daniel Costa ${ }^{1}$, Fabio Paulino ${ }^{1}$, Helton Lourenço ${ }^{1}$ and Evangelos Albanidis ${ }^{2}$ \\ ${ }^{1}$ Laboratory of Exercise Physiology, Lafiex, Estácio de Sá University, UNESA, Rio de Janeiro, Brazil \\ ${ }^{2}$ Democritus University of Thrace, Greece
}

Submission: February 23, 2019; Published: March 11, 2019

*Corresponding author: Thiago Guimarães, Laboratory of Exercise Physiology, Lafiex, Estácio de Sá University, Rio de Janeiro, Brazil

\begin{abstract}
Olympic Games and its values were the most influential sporting phenomenon in western civilization, impacting in the development of democracy and health. The cult of physical effort in harmony is one of the numerous ideas inherent to Olympic education. The purpose of this work was to investigate the basic knowledge of university students of physical education from one university of Rio de Janeiro, Brazil, about Olympism and concepts related to excessive training. A closed questionnaire was applied to 433 students, divided into four different groups: first year of degree $(n=128)$, second year $(n=107)$, third year $(n=90)$ and fourth year $(n=108)$. Physical education students were not able to identify the broad meaning of Olympism besides the crucial idea of harmony and moderation in training - in general, only $35,51 \%$ of correct answers were counted. Although Rio de Janeiro has hosted the last Olympic Games, the legacy in the area of Olympic Education is questionable. Olympism in university could provoke future physical education teachers to rethink paradigms, as the culture of pain without moderation, and values associated to the human progress, as an appreciation of sports and health with balance and responsibility.
\end{abstract}

Keywords: Olympic Education; Olympic Games; Overtraining

\section{Introduction}

Sport can be understood as a motor behavior that influences social and cultural relations for centuries [1]. In Ancient Greece, athletic and gymnastic activities were part of the ideal of formation citizens with a direct impact on the origin and construction of democracy. In addition to transmitting moral, pedagogical and educational values, the Greek games had a religious character (ideals, rituals, celebrations), where the gods of Olympus were honored. The Olympic Games also promoted cultural exchange and peace among the Greek peoples [2]. The Olympic Games of the modern era propagated sport and Olympism throughout the world. According to International Olympic Committee Charter, "Olympism is a philosophy of life, exalting and combining in a balanced whole the qualities of body, will and mind. Blending sport with culture and education, Olympism seeks to create a way of life based on the joy of effort, the educational value of good example, social responsibility and respect for universal fundamental ethical principles" [3]. Thus, there is a space for Olympic education, which includes the need for education around the universal values (peace, love, solidarity), through those values and to the Olympic values like excellence, respect and friendship in mutual understanding, truly universal in their humanistic sense [4].

Health is also an inherent subject of Olympism. According to one of the main articulators of the modern Olympics, Baron de Coubertin, the cult of physical effort should exist within a harmonious context, that is, the appreciate for excess should be combined with moderation. In fact, since before Christ, there was already a concern with the possible deleterious repercussions of excess exercise in relation to health [5]. Hippocratic, Plato and Aristotle claimed that any exaggeration could turn against nature and clearly declared that overtraining is always wrong [5]. The Hippocratic philosophy on health care provision focused on the holistic health care model, applying standards and ethical rules that are still valid today. The ancient Greeks believed that mental and physical health were interrelated as they had found that the body and mind should be in harmony and balance [6]. 
Although hundreds of years have been believed that sports and gymnastics are essential to the development of the human body to optimize functional capacity and mind [6], the try to propagate the idea "Sports to protect the health" [7] and "wellbeing and healthy lifestyle" International Olympic Committee [3], in addition to increasing research in the field of exercise sciences and sports, we are experiencing a worldwide pandemic of physical inactivity [8]. Physical inactivity is one of the main causes related to the development of non-communicable chronic diseases, such as cardiovascular diseases, diabetes, several types of cancer, mental disorders, bones and joints $[9,10]$. According to the World Health Organization (2012), in addition to causing suffering, functional dependence, intangible costs on health systems and reduced quality of life, these diseases account for $58.5 \%$ of all deaths worldwide.

On the other hand, although the prevalence of symptoms of overtraining is rarely studied, it is estimated that $60 \%$ of marathon runners, $50 \%$ of soccer players and $33 \%$ of basketball players have already experienced them [11,12]. Amateur, professional or recreational athletes are frequently affected by disorders of metabolic, immunological, neurological, endocrine, cardiovascular and musculoskeletal origin. These changes are characteristic of the overtraining syndrome [13]. Physical inactivity is a public health problem and overtraining can also contribute to the development of pathologies and reduction of quality of life. Olympic education seems to be a tool to stimulate discussions that promote people's health through exercise and sports. In this sense, the purpose of this work was to investigate the basic knowledge of university students of physical education from a Brazilian's city about Olympism and general concepts related to excessive training. We tested the hypothesis that physical education students are not able to identify the broad meaning of Olympism besides the crucial idea of harmony and moderation in training.

\section{Methods}

Participated in this study 433 students of physical education of a university from Rio de Janeiro, Brazil. The participants were divided into four different groups: first year of degree $(n=128)$, second year of degree $(n=107)$, third year of degree $(n=90)$ and fourth year of degree $(n=108)$. A questionnaire with four questions and objective answers was applied to approach the knowledge about Olympism (two questions) and concepts related to the paradox of exercise (two questions). We performed a descriptive analysis to characterize the sample (mean and standard deviation of age) and define the percentage of positive or correct responses. We performed a one way ANOVA in the four answers of the questionnaire to verify possible differences between the different years of graduation. All statistical procedures were performed in the statistical program Graphpad Prism 5.01@, assuming the level of significance $\mathrm{P}<0,05$.

\section{Results}

Table 1 reveals answers that we considered corrects (expressed in percentage) for each question performed by the students from different year of degrees. Question 1 (Q1): "Have you ever heard about Olympism?" We found significant difference between students from third versus first year of degree, and between third versus fourth year of degree $(\mathrm{P}<0,05)$. Question $1 \mathrm{a}$ (Q1a): If the answer was positive in the previous question, students should choose from five different options to express the meaning of Olympism ("cult of aesthetics", "philosophy", "cult of the body", "religion" or "science"). Correct answer is "philosophy." There was no significant difference between students from different years of degree. Question 2 (Q2): "The athletes need to live outside the comfort zone to achieve their goals. Check the option most compatible with your opinion on the affirmation: never, eventually or always." We considered "eventually" as the correct answer. We found significant difference between students from first versus second year of degree $(\mathrm{P}<0,05)$. Question 3 (Q3): "Exercise and sport always produce benefits. Check the option most compatible with your opinion on the affirmation: yes or no." We considered that this statement is not correct. We found significant difference between students from first versus second, first versus third, second versus fourth year of degree $(\mathrm{P}<0,001)$, and between students from third versus fourth year of degree $(\mathrm{P}<0,05)$. In general, only $35,51 \%$ of correct answers were counted.

Table 1: Results of correct answers (expressed in percentage) for each question performed by the students from different year of degrees.

\begin{tabular}{|c|c|c|c|c|c|c|}
\hline & Total of students & $\begin{array}{c}\text { Students from } 1^{\text {st }} \\
\text { year }\end{array}$ & $\begin{array}{c}\text { Students from } 2^{\text {nd }} \\
\text { year }\end{array}$ & $\begin{array}{c}\text { Students from } 3^{\text {rd }} \\
\text { year }\end{array}$ & $\begin{array}{c}\text { Students from } 4^{\text {th }} \\
\text { year }\end{array}$ & $\mathbf{P}$ \\
\hline Sample & 433 & 128 & 107 & 90 & 108 & --- \\
\hline Age (years) & $27 \pm 6,99$ & $25 \pm 7,55$ & $26 \pm 6,95$ & $27 \pm 7,10$ & $29 \pm 6,34$ & --- \\
\hline Q1 & $27,37 \%$ & $21,09 \%$ & $25,23 \%$ & $40 \% *$ & $23,15 \%$ & $* \mathrm{P}<0,05$ \\
\hline Q1a & $34,93 \%$ & $29,63 \%$ & $40,74 \%$ & $33,33 \%$ & $36 \%$ & NS \\
\hline Q2 & $42,73 \%$ & $53,91 \% *$ & $34,58 \%$ & $44,44 \%$ & $37,97 \%$ & $* \mathrm{P}<0,05$ \\
\hline Q3 & $36,99 \%$ & $15,63 \%$ & $29,91 \% \#$ & $42,22 \% \#$ & $60,19 \% * \#$ & $\# \mathrm{P}<0,001 * \mathrm{P}<0,05$ \\
\hline
\end{tabular}

\section{Discussion}

The purpose of this work was to investigate the basic knowledge of university students of physical education from Rio de Janeiro, Brazil, about Olympism and general concepts related to ex- cessive training. We tested the hypothesis that physical education students are not able to identify the broad meaning of Olympism besides the crucial idea of harmony and moderation in training. We confirm the tested hypothesis because the basic knowledge 
about Olympism and concepts related to negative impact of physical exercise does not predominate among students, regardless of the year of graduation. The only exception applies to the sport and exercise-related question always yields benefits, which $60 \%$ of the students in the last year of graduation have correctly answered, differing statistically in comparison to the other years of graduation. One of the main objectives of the Olympic Movement and Olympism is to provoke reflection about values essential to human development, gradually compromised in the modern world by capital power [1]. In addition to tolerance, equality, fair play, truce, search for excellence and personal achievement through the effort itself, Olympic Education also has the role of discussing the promotion of health, respect for oneself, your body and the other [3].

The promotion of health, although already considered by researchers and professionals of Physical Education and Sport Sciences in different countries, has not received enough attention in the context of the Brazilian Olympic Education [1]. The subject health promotion appeared during the ancient Olympic Games since the care of athletes and prevention of injuries were specialist services provided by instructors [6]. Discussions in this context are important because of their educational dimension and the understanding that health promotion is directly related to Olympic principles and values. Physical inactivity is something discussed since antiquity, as well as overtraining and abuse of exercise. The ancient Greek ideals of exercise and health have influenced the attitude of modern western culture toward exercise and physical activity and played an important role in the practice of preventive hygiene. On the other hand, Hippocratic, Plato and Aristotle claimed that any exaggeration could turn against nature and clearly declared that overtraining is always wrong [5]. Besides exercise, they were also discussed the role of music and theater in the treatment of physical and mental illnesses and the improvement of human behavior [6].

We can see nowadays that physical inactivity continues to represent an important public health problem and, on the other extreme side, the no pain no gain culture seems to prevail [4, $14,15,13]$. Harmony, moderation and balance are words that have not lost their importance. In the context of sports, every athlete needs to train strenuously, but there are specific periods for that. Coaches, physiologists, and all other components of an athlete's technical team need to be aware of the fine line between the risks and benefits of overtraining. We can see that athletes not only in our times but also in ancient times suffered from health injuries due to extreme exercise [5]. The sport was diffused from the Olympic Games of 786 before Christ and influenced the development of Western society from different perspectives. The sport has impacted on the formation of citizens, democracy, economy, religion and health [2]. It is not a trivial topic. However, most physical education students unaware of the historical significance of such phenomena. It is speculated that the way by which sport promoted the development of society resides in moral principles and aggregate values, such as respect, tolerance, fair play, excellence. Olympism is a philosophy that tries to rescue this conception, in favor of human evolution. It is a fact that this way is not the only one in favor of human development, but when it comes to physical education, it can be an excellent argument for the implementation and appreciation of its practice in schools, clubs, squares, parks, as well as professional valorization involved in its application [1]. It is necessary to develop in the city investigated and possibly other parts of Brazil awareness programs about the historical significance of sport and its added values.

Olympic Education aims to protect and promote common interests of society such as health, peace, friendship and progress. Olympism, in the face of capital power, can serve as an important provoking tool of a value system and, as such, an ideology in the service of human development [1]. Its pedagogical content includes humanist principles universally accepted by society. However, although Rio de Janeiro hosted the last Olympic Games, Olympism does not seem to have been propagated in a manner compatible with its relevance. Students of Physical Education are not able to identify their meaning, as well as important concepts such as harmony and moderation. Olympic education in universities could contribute to an assimilation and propagation of fundamental values to the human progress. Integration policies between international and national Olympic committees could provide training for university teachers in relation to Olympic Education. University students and future professionals, in turn, could multiply and spread their content in society, leading them to rethink paradigms, perceive that sport is essential in many aspects and make it more critical of so many possible legacies.

\section{Conclusion}

Although Rio de Janeiro has hosted the last Olympic Games, the legacy in the area of Olympic Education is questionable. Olympism in university could provoke future physical education teachers to rethink paradigms, as the culture of pain without moderation, and values associated to the human progress, as an appreciation of sports and health with balance and responsibility.

\section{References}

1. Reppold Filho AR, Pinto LMM, Rodrigues RP, Engelman S (2009) Olimpismo e Educação Olímpica no Brasil. Porto Alegre: UFRGS.

2. Crowther NB (2007) Sport in Ancient Times. London: Praeger.

3. (2013) International Olympic Committee.

4. Guimarães T (2018) Excessive Exercise, Self-Respect and Olympic Education: Legacy in Rio de Janeiro-2016. Journal of Physical Fitness, Medicine and Treatment in Sports 4(1).

5. Albanidis E (2013) Exercise in Moderation. Health Perspective of Hellenic Antiquity. Nikephoros 26: 33-62.

6. Kleisiaris CF, Sfakianakis C, Papathanasiou IV (2014) Health care practices in ancient Greece: The Hippocratic ideal. J Med Ethics Hist Med 7(6).

7. International Olympic Committee (2007).

8. Hallal PC, Andersen LB, Bull FC, Guthold R, Haskell W, et al. (2012) Global physical activity levels: surveillance progress, pitfalls, and prospects. Lancet 380(9838): 247-257. 
9. Handschin C, Spiegelman BM (2008) The role of exercise and PGC1alpha in inflammation and chronic disease. Nature 454(7203): 463-469.

10. Lee IM, Shiroma EJ, Lobelo F, Puska P, Blair SN, et al. (2012) Effect of physical inactivity on major non-communicable diseases worldwide: an analysis of burden of disease and life expectancy. Lancet 380(9838): 219-229.

11. Armstrong LE, VanHeest JL (2002) The unknown mechanism of the overtraining syndrome: clues from depression and psychoneuroimmunology. Sports Med 32(3): 185-209.

12. Matta Mello Portugal E, Cevada T, Sobral Monteiro-Junior R, Teixeira Guimarães T, Da Cruz Rubini E, et al. (2013) Neuroscience of exercise: from neurobiology mechanisms to mental health. Neuropsychobiology 68(1): 1-14.

13. Guimarães TT, Terra R, Dutra P (2017) Chronic effects of exhausting exercise and overtraining on the immune response: Th1 and Th2 profile. Journal Motricidade 13(3): 69-78.

14. Guimarães TT (2016) Paradoxo do exercício físico em excesso: linha tênue entre riscos e benefícios. Revista Eletrônica Nacional de Educação Física 6(8).

15. Guimarães TT, Carvalho M, Santos W, Rubini E, Coelho W (2017) Crossfit, weight training and running addiction, injuries and immunological vulnerability. Journal of Physical Education 86(1).

\section{Your next submission with Juniper Publishers} will reach you the below assets

- Quality Editorial service

- Swift Peer Review

- Reprints availability

- E-prints Service

- Manuscript Podcast for convenient understanding

- Global attainment for your research

- Manuscript accessibility in different formats ( Pdf, E-pub, Full Text, Audio)

- Unceasing customer service

Track the below URL for one-step submission https://juniperpublishers.com/online-submission.php 